\title{
English teachers' attitudes toward inclusive education: A literature review
}

Recibido: 28/10/2015

Aceptado: 17/12/2015

\author{
Actitudes de los docentes de inglés acerca de la educación \\ inclusiva: revisión del estado del arte
}

\author{
Paula Andrea García Montes, paulandreag02@gmail.com \\ Jaime Nieto Caballero, nietojaime@hotmail.com \\ Universidad de Córdoba, Colombia
}

César Arbeláez Rodríguez, arbelaezrodriguez93@gmail.com

Universidad del Sinú, Colombia

\section{Abstract}

This paper reports a review of literature concerning the attitudes of teachers toward inclusive education of children with disabilities. This paper reviews a large body of research-based literature, in order to explore the factors and reasons that might impact teachers' attitudes concerning the teaching of disabled children. The analysis was carried out to show evidence of positive and negative views of teachers towards inclusion. Throughout the analysis, teachers' attitudes were found to be influenced by their general philosophy of inclusion and the way they perceived that inclusion should be implemented. After analyzing the results of various research studies, it was found that teachers' positive or negative attitudes depended on many factors such as knowledge toward inclusive education, time, resources and professional development.

Keywords: Inclusion, policies and teachers' attitudes.

\section{Resumen}

Este artículo reporta un análisis del estado del arte sobre las actitudes de los profesores hacia la educación inclusiva de niños con discapacidad. Este artículo analiza una variedad de investigaciones con el propósito de explorar los factores y las razones que pueden incidir en las actitudes de los profesores sobre la enseñanza a niños discapacitados. El análisis fue llevado a cabo para mostrar evidencia de las perspectivas positivas y negativas de los profesores hacía la inclusión. Durante todo el análisis, las actitudes de los profesores resultaron ser influenciadas por su filosofía general de inclusión y la percepción de como debería ser implementado este proceso. Después de discutir los resultados de los estudios analizados, se encontró que las actitudes positivas o negativas dependía de una variedad de factores como el conocimiento de educación inclusiva, tiempo, recursos y desarrollo profesional.

Palabras claves: Inclusión, políticas y actitudes de los docentes. 


\section{Introduction}

Colombian educational institutions are required by national and international regulations to foster inclusion of disabled learners in mainstream environments (e.g., U.N., Convention on the Rights of Persons with Disabilities, art 24; Australia Ministry of Education and Training, Disability Standards for Education, 2005), generating inclusive practices that cater for all learners regardless of their condition. A variety of studies have reported differing attitudes from teachers facing the challenge of inclusion of disabled students in mainstream classrooms that such regulations pose. The purpose of this article is to review that research, analyzing the variety of teachers' attitudes to inclusion and their possible implications for research and practice. Following Eagly and Chaiken's (1993) and Zanna and Rempel's (1988) multicomponent conceptualization of attitudes, including cognitive, affective and behavioral components, we focus on the affective component of teachers' attitudes.

Overall, teachers' views may stem from a variety of factors that can lead teachers to favorable thoughts or to feelings against any kind of inclusive practice with disabled children in schools. Some educators may consider inclusive education as "normalization", which is a concept related to equity, opportunity, social valorization and equality (Bank-Mikkelson, 1969; Nirje, 1970; Wolfensberger, 1970). These teachers may accept disabled learners, involving them in the learning and teaching process with regular learners, highlighting the right of all individuals to be part of communities sharing the same rights. On the other hand, teaching disabled children may be unusual for the mainstream classroom teacher, since they may oppose any idea of inclusion that may lead to extra work or may require specialized knowledge.

The first section of this paper describes the main concepts in the field of inclusive education and policies. Section two reviews research studies concerning teachers' attitudes when teaching disabled learners, whereas section three analyses relevant issues gathered from the studies. The paper concludes with suggestions for further research.

\section{Main concepts in the field of inclusive education 1 Inclusion}

Inclusion refers to the practice of allowing all students, regardless of their disability, to participate and have a full access to education (Mastropieri and Scruggs, 2004). According to Carrington and Elkin (2002), the philosophy of inclusion incorporates respect toward all students accepting and valuing them with their gifts, disabilities and different learning styles. That is to say, inclusive education recognizes that all students learn at different paces and in different ways, and provides opportunities for learning to disabled and nondisabled students.

Inclusion means that the student must have access to all the supports and services needed to participate fully in educational activities and curriculum (Burstain, Sears, Wilcoxen, Cabello \& Spagna, 2004; Downing \& Eichingger, 2008; Mulvibill, Cotton \& Gyaben, 2004; Pivik, McComas \& LaFlamme, 2002). From this it stems that all students, including those with disabilities and special needs, should be educated in the same classroom environment as other students (Porter, 2008).

Bearing this in mind, schools and universities have been accommodating their curricula in order to provide equitable participation to students in all school activities, spaces and processes (Kleinert, Miracle, \& Sheppard-Jones, 2007; Thomson et al., 2003) Effective inclusive education in schools provides, according to Ferguson (1995), high-quality learning with meaningful curriculum and an efficient teaching to each child with no regard of their learning styles, preferences and paces. Accordingly, educational instituctions need a variety of facilities and resources such as assistive technology (AT), adapted curriculum, materials and other services to guarantee a successful and 
pleasant learning experience to all.

On the other hand, teaching to disabled children in mainstream classroom can be an unusual situation for the clof inclusive schools.

Inclusion means that the student must have access to all of the supports and services he or she will need to participate fully in general education activities and curriculum (Burstain, Sears, Wilcoxen, Cabello \& Spagna, 2004; Downing \& Eichingger, 2008; Mulvibill, Cotton \& Gyaben, 2004; Pivik, McComas).

\section{Policies about inclusion}

Irrespective of the barrier faced by teachers and students, inclusive education is clearly understood by the government, schools, and the wider community, as the possibility that children with disabilities be educated on an equal basis as non-disabled learners. Table 1 shows an overview of international frameworks and regulations about inclusion.

These policies set out an overall vision: universalizing access to education for all children, adults, and youth. The major impetus for the implementation of inclusive education was given by World Conference on Special Needs Education for all held in Salamanca, Spain, June (1994), where more of 300 hundred participants considered the fundamental shifts that are needed to promote inclusive education, thereby, enabling all institutions to serve children, especially those with disabilities. The vision of these policies is to promote inclusive education in all contexts so that schools can accommodate all children regardless of their physical conditions, linguistics needs, intellectual, social, emotional and other types of conditions. This vision was reaffirmed by World Education Forum (Dakar, April 2000), held to declare that education for all must consider the needs of the poor and disadvantage including minorities and working or disabled children. Inclusion is thus seen as a process of addressing diversity in schools through increasing the participation of all in learning, communities and cultures in order to reduce and eliminate exclusion, (UNESCO, 2003b).

Furthermore, there is a growing consensus around the world concerning inclusive practices and the right that all children have to be educated. In the last eight years, statements and policies have insisted on the importance of promoting inclusive practices in mainstream contexts. For instance, the Salamanca Statement (1994), highlights the importance of "working towards schools for allinstitutions which include everybody, celebrate differences, support learning and respond to individual needs" (p. 6). Likewise, the UN Convention on the Rights of the Child (1989), the UN Standard Rules on the Equalization of Opportunities for Persons with Disabilities (1993) and UNESCO (1994) are meaningful international statements against segregation and denying children with disabilities the right to be part of schools and society.

Similarly, All Handicapped Children Act (1975) is one of the most important international provisions ensuring that all children have the right to be educated and presented with free and appropriate education in the least restrictive environment. Rights of special needs students were expanded under subsequent laws, particularly, the Education for People with Special Educational Needs (EPSEN) Act of 2004, which explains that:

Special educational needs are restrictions in the capacity of the person to participate in and benefit from education on account of an enduring physical, sensory, mental health, learning disability, or any other condition which results in a person learning differently from a person without that condition (p.10).

With the idea of inclusion, all nations around the world mandate that new teachers become acquainted with techniques and strategies for working with all types of special needs students. In order 
to realize the right of education outlined in these policies, the World Declaration further stipulated that learners are humans with different and diverse characteristics and backgrounds, hence the strategies used to improve their learning process should therefore draw on their capabilities, strengthens and knowledge.

Table 1. International policies about inclusion

\begin{tabular}{|c|c|c|}
\hline Year & Policies & Focus \\
\hline 2007 & $\begin{array}{l}\text { United Nations Declaration on the Rights of } \\
\text { Indigenous Peoples }\end{array}$ & $\begin{array}{l}\text { It recognizes "the right of all peoples to be different, to consider } \\
\text { themselves different, and to be respected as such" (p. 1). }\end{array}$ \\
\hline 2006 & $\begin{array}{l}\text { Convention on the Rights of Persons with } \\
\text { Disabilities }\end{array}$ & $\begin{array}{l}\text { It ensures the right to access to education, the right to quality } \\
\text { education and the right to respect in the learning environment. }\end{array}$ \\
\hline 2005 & $\begin{array}{l}\text { Convention on the Protection and Promotion } \\
\text { of Diversity in Cultural Expressions }\end{array}$ & $\begin{array}{l}\text { It advocates for cultural diversity, flourishing within a } \\
\text { framework of democracy, tolerance, and social justice between } \\
\text { peoples and cultures,"( } 21 \text { October } 2005 \text { at its } 33 \text { rd session) }\end{array}$ \\
\hline 2000 & $\begin{array}{l}\text { World Education Forum and the Dakar } \\
\text { Framework for Action. }\end{array}$ & $\begin{array}{l}\text { "...it has re-stated a global commitment to the achievement } \\
\text { of Education for All as a fundamental right for all children". } \\
\text { (Article 19) }\end{array}$ \\
\hline 1975 & $\begin{array}{l}\text { The Education for all Handicapped children } \\
\text { (EHA) }\end{array}$ & $\begin{array}{l}\text { It guides school systems in how they design and implement the } \\
\text { special education and related service program..(p. 1. 94-142) }\end{array}$ \\
\hline 1999 & $\begin{array}{l}\text { Convention concerning the Prohibition and } \\
\text { Immediate Actionfor the Elimination of the } \\
\text { Worst Forms of Child Labour }\end{array}$ & $\begin{array}{l}\text { It protects indigenous languages, } 13 \text { both provide further } \\
\text { international support for inclusive education }\end{array}$ \\
\hline 1990 & $\begin{array}{l}\text { International Convention on the Protection } \\
\text { of the Rights of All Migrant Workers and } \\
\text { Members of their Families }\end{array}$ & $\begin{array}{l}\text { It advocates for the "Promotion of Equality of Opportunity } \\
\text { and Treatment of Migrant Workers" (No.143) }\end{array}$ \\
\hline 1990 & $\begin{array}{l}\text { World Conference on Education for All, } \\
\text { Jomtien, Thailand }\end{array}$ & $\begin{array}{l}\text { Its goal is to focus on providing educational opportunities } \\
\text { designed to meet basic learning needs in a more flexible } \\
\text { manner, responding to the needs, culture and circumstances of } \\
\text { learners. (Article } 3 \text { ) }\end{array}$ \\
\hline 1994 & $\begin{array}{l}\text { Salamanca Statement and Framework for } \\
\text { Action on Special Needs Education }\end{array}$ & $\begin{array}{l}\text { It stated that special needs education for children with } \\
\text { disabilities and those with learning difficulties could not } \\
\text { advance in isolation but must form part of an overall } \\
\text { educational strategy. (Art.2) }\end{array}$ \\
\hline 1989 & Convention on the Rights of the Child & $\begin{array}{l}\text { It sets out the civil, political, economic, social, health and cul- } \\
\text { tural rights of children. }\end{array}$ \\
\hline 1965 & $\begin{array}{l}\text { International Convention on the Elimination } \\
\text { of All Forms of Racial Discrimination }\end{array}$ & $\begin{array}{l}\text { It proclaims that "...all human beings are born free and equal in } \\
\text { dignity and rights and that everyone is entitled to all the rights } \\
\text { and freedoms"( } 21 \text { December 1965) }\end{array}$ \\
\hline 1960 & $\begin{array}{l}\text { Convention against Discrimination in } \\
\text { Education }\end{array}$ & $\begin{array}{l}\text { It abrogates any statutory provisions and any } \\
\text { administrative instructions and to discontinue any } \\
\text { administrative practices which involve discrimination in } \\
\text { education. }\end{array}$ \\
\hline 1945 & UNESCO Constitution. & $\begin{array}{l}\text { It proclaims that everyone has the right to education, } \\
\text { free and compulsory at the "elementary" stages, with } \\
\text { technical and professional education made generally } \\
\text { available and higher education equally accessible to all. } \\
\text { (Article 26) }\end{array}$ \\
\hline
\end{tabular}


Through the implementation of Differentiated Instruction (henceforth DI) to include disabled students, many nations have took action to improve their educational systems by "recognizing students' varying background knowledge, readiness, language, preferences in learning, interests, and to react responsively" (Hall, 2002, p. 4). Nowadays, policies to support disabled people are also established in Colombia, summarized in Table 2.

Table 2. Colombian Mandates regarding Inclusion

\begin{tabular}{lll}
\hline Year & Policies & Focus \\
\hline 2013 & $\begin{array}{l}\text { Inclusión- revolución educativa Ministerio } \\
\text { de Educación Nacional, política de educación } \\
\text { inclusiva en Colombia (Decree 366-2009) }\end{array}$ & $\begin{array}{l}\text { It gives priority to education of vulnerable pop- } \\
\text { ulations and within them. To make them produc- } \\
\text { tive so they become autonomous and strengthen } \\
\text { social their relations. }\end{array}$ \\
2011 & $\begin{array}{l}\text { Asamblea Nacional Constituyente (National } \\
\text { Constituent Assembly) }\end{array}$ & $\begin{array}{l}\text { It creates inclusion that provisions that addressed } \\
\text { ethnic and race-based interests, like communal } \\
\text { land rights and political participation }\end{array}$ \\
& $\begin{array}{l}\text { Law of Anti-Discrimination, No. 1482, 2011 } \\
\text { It contains the antidiscrimination bill, and in No- } \\
\text { vember of the same year President Juan Manuel } \\
\text { Constitución política de Colombia de 1991, } \\
\text { Laws 115 de Educación de 1994, 361 - 1997, } \\
\text { 1098 de 2006, Decree 366 de 2009, and law } \\
\text { 1346 de 2009 , law 762 }\end{array}$ & $\begin{array}{l}\text { It advocates that parents of children with disabil- } \\
\text { ities should not struggle finding available spaces } \\
\text { at Institutions. It is the responsibility of the } \\
\text { school to accommodate differences in learners. }\end{array}$
\end{tabular}

As these regulations imply, the practice of educating students with special needs in the same classroom as non-disabled students is mandatory. Articles 13, 47, 54 and 68 from the Colombian Constitution establish the legal framework for the rights of disabled people, as well as the obligations of state administrators and society in general regarding inclusive education. In these mandates, obligations about care, support, and social integration of disabled people are also expressed. In May 2001, law 762 (Congress of the Republic of Colombia, 2001) approved the inter-American convention for the elimination of all kinds of discrimination against people with disabilities. In addition, The National Education Ministry has made advances in the design of regulations for inclusion and integration in order to align educational policies and practices with the requirements of disabled students learning in mainstream classrooms (Mobilla, 2011).

\section{$3 \quad$ Attitudes}

Attitudes are defined by Eagly and Chaiken (1993) as general evaluations that an individual executes, represented as expressions of favor or disfavor toward what has been defined as attitude object. This attitude object can be a place, an animal, an object or a person; in the educational field it can refer to students as well. Thus, individuals' attitudes can be affected by the attitude object and the representation an individual has of it. To explain this relation, Eagly and Chaiken (1993) and Zanna and Rempel (1988) proposed a multicomponent model of attitudes. This model has three components: the cognitive component, the affective component and the behavioral component. The cognitive component refers to the beliefs, thoughts, and attributes that people attach to an attitude object. For 
instance, "an individual's favorable attitude toward a particular politician might be based on the belief that the politician is charismatic, intelligent, and has economic policies that promote social equality." The affective component refers to the feelings people attach to an attitude object. For instance, "many people indicate that spiders make them feel scared. This negative affective response is likely to cause a negative attitude toward spiders." The behavioral component refers to the past experiences that can be attached to an attitude object. For instance, "people might guess that they must have a negative attitude toward factory farming, if they remember having signed a petition against the unethical treatment of animals" (Maio and Haddock, 2009, p. 2-3). In sum, attitudes can be considered as tendencies that result from a congregation of beliefs, feelings and behaviors which express favorability or not toward an object (Hogg and Vaughan, 2005).

In educational settings, an attitude of disfavor toward students by their teacher might make the former feel anxious, nervous, and shy, resulting in apathy and aversion toward lessons. In contrast, when teachers keep a healthy learning environment, students' desire for participation may increase. Effective teachers are willing to share emotions and feelings of enthusiasm, affection, disapproval, criticism, sadness, interest or care about students, teaching tools and laws. Thus, attitudes can be expressed by the teacher through sensitively accepting diversity or refusing it, which is the main concern in this literature review.

\section{Methodology}

The methodology used for this literature review was to systematically search for research articles about inclusion in databases like Eric and Science Direct, journal sources such as Sage, and General search engines like Google Scholar. Searches were also made of online reports and international dissertations. Information gathered was organized into topics that were then described as chapter headings. The search descriptors used were teachers' attitudes about inclusive education, pre-service teachers' beliefs about inclusive education, teachers' feelings about inclusive practices, special educational needs, inclusion and professional development. Findings and research from 90 sources including journals, online reports and dissertations were analyzed with a few exceptions, since some of the data gathered were not particularly significant or related to teachers' attitudes. A number of research studies discussed the effectiveness of different approaches to the preparation of pre-service teachers for inclusion. Unfortunately, little research had studied teachers' attitudes toward the inclusion of students with special needs in mainstream classes. Accordingly, only 30 studies were considered in this review.

\section{Positive and negative attitudes towards implementing inclusive education}

Our review of the research revealed three main categories related to teachers' attitudes towards inclusion: 1) positive attitudes, 2) acceptance of a total inclusion, and 3) negative attitudes towards inclusive education.

a Positive attitudes: Teachers' leadership, advocacy and knowledge about inclusion: Teachers' leadership, advocacy, and knowledge for inclusion are essential to developing inclusive practices in mainstream classrooms. Indeed, teachers who are successful managers and leaders of inclusion may hold positive attitudes that motivate themselves to continue refining their teaching practices. A study carried out by Dev and Belfiore (1996) explored and examined 95 teachers' attitudes involved in the implementation of inclusive practices in Delhi schools. Teachers were favorable and disposed to the teaching of disabled children and the implementation of inclusive ideas in regular contexts. They showed empathy to the application of inclusive practices and felt concern about having training and 
knowledge to handle disability. In another research, Elliot (2008) conducted a study that examined teacher attitudes concerning inclusion of children with mental disabilities. Findings suggested a close relationship between teachers' attitudes and their relationship to the development of inclusive practices. The study revealed that teachers with positive attitudes and commitment toward inclusion enacted teaching practices that led to higher levels of acceptance and success. Likewise, Avramidis, Bayliss and Burden (2000) developed a survey study addressing the attitudes of 81 primary and secondary teachers toward the inclusion of children with special education needs in a traditional school in England. They discovered that teachers that were active in an inclusive program and thus had experience with inclusion tended to have more positive attitudes.

Lynn (2005) investigated the advantages of DI to achieve inclusive purposes. The study found that adapting the curriculum and implementing inclusive strategies and methods helped her students to develop classroom activities and expanded their interests when working with others. These practices led to the development of positive interactions between the teacher and students with disabilities. The rest of the students, on the other hand, demonstrated more acceptance of their partners' differences and showed an appreciation for one another. Lynn finally found that teachers' leadership and knowledge about inclusive practices encouraged acceptance among students and helped the teacher to display favorable attitudes towards the teaching of children with special needs.

Bowman (1986) conducted a UNESCO study with 1000 teachers from Mexico, Venezuela, Senegal, Australia, Portugal, and Norway that had knowledge about inclusive education in order to describe their opinions about integration. Findings revealed that teachers provided students with a variety of pedagogical tools to engage students with special education needs (SEN) in their classrooms. Bowman also noted that teachers who had little support and provision to include disabled students were more supportive of integration.

Two more studies were carried out by Beh-Pajooh (1992) and Shimman (1990), with teachers in colleges from UK who taught students with special needs that were integrated in ordinary college courses. They administered several interviews in order to search for teachers' thoughts concerning inclusion. Findings revealed that college teachers who had been trained to face challenges of inclusion, showed favorable attitudes and emotional reactions to students with special needs.

Gelzheiser and Meyers (1996) conducted a case study to describe teachers' attitudes as predictors for student success or failure. The study found that teachers' attitudes and beliefs toward inclusion are powerful predictors of efforts to create spaces that promote inclusion for all. They found that most of the teachers involved in the study showed commitment and advocacy for total inclusive learning environments. Their findings also revealed that when teachers are positive to the teaching of disabled children in mainstream contexts, students with and without disability enjoy their learning process and succeed in the regular educational system.

Joseph Agbenyega, (2007) conducted a study that examined 100 teachers' attitudes and concerns toward inclusive education of children with disabilities in Ghana. A Scale with 20 items was applied containing aspects about inclusive education, it was completed by 100 teachers from different inclusive projects in three different localities: central business, coastal and suburban areas within the Greater Accra metropolis. The study revealed that there were many factors that influenced teachers' positive attitudes toward inclusion such as behavioral issues, student needs, professional competency, and resources. Results also showed that teachers looked for quick answers in order to meet the needs of students with disabilities.

Another study was conducted by Subban (2005) to investigate teachers' attitudes and concerns about inclusive practices. The investigation was based on semi-structured interviews conducted with 
42 mainstream teachers in state schools in Australia. The study revealed that teachers were mainly positively inclined towards the philosophy of inclusion. They perceived this process as something beneficial to all participants within the classroom or inclusive setting. However, some of them remained cautious about including students with severe disabilities.

Kern (2006) also investigated about attitudes of K12 regular and special education teachers regarding inclusive education in urban Pennsylvania. The study examined attitudes held by these teachers and their foundations of knowledge and experiences that shaped their attitudes. Teachers in a small, urban school district were chosen as the population for this study. Interviews revealed that teachers held very positive attitudes to collaborate and build inclusive settings; however, they considered that they needed more training and support from the district.

b Professional development : Many studies have revealed that teachers who show positive views towards inclusive practices are more likely to challenge themselves in order to increase their knowledge, finding strategies to teach more effectively. Bender, Vail and Scott (1995) researched teachers' attitudes toward mainstreaming and its consequences on the use of effective instructional strategies for students with learning disabilities. Their study involved 127 mainstream teachers who were assessed regarding mainstream attitudes, teaching efficacy and instructional strategies. The results revealed that teachers who had more positive attitudes toward mainstreaming put into practice more instructional strategies and were eager to accommodate materials and instruction, in contrast to teachers who had negative attitudes and strong beliefs towards teaching children with physical disabilities. They also showed empathy to grow professionally in the field of inclusion to favor the learning process of SEN students. Likewise, Villa et al. (1996) reported that teachers favored the inclusion of children with special needs in ordinary schools, which demonstrates their support of the idea of educating disabled children in regular schools. The authors found that, having implemented a complete cycle of inclusive education, teachers showed commitment and gained mastery of the professional expertise needed to carry out inclusive education, due to their strong and favorable attitudes concerning disabilities. In addition, they expressed the need to keep working on their knowledge and strategies to continue promoting inclusion.

Continuing with the same line of ideas, teachers have demonstrated evidence of positive attitudes of acceptance towards inclusive practices in mainstream classes. A clear example of a large number of teachers showing positive concerns to grow professionally in the field of inclusion and face the challenge of teaching disabled children can be identified in the following studies, where teachers put a lot of effort in modifying their classroom practices in order to change their regular instruction to more inclusive teaching practices. Al-Zyoudi (2006) explored teachers' attitudes toward inclusion of children with disabilities in Jordan and the causes of such attitudes. The findings showed that the majority of teachers agreed on the necessity for changes in public schools in order to accomplish the needs of students with disabilities. They also emphasized the importance of improving their knowledge and skills on inclusion that could certify them as specialists. Another study was carried out by Khaouli (2014) focusing on teachers' adaptation of classroom environment and use of teaching strategies implemented to teach visually impaired (VI) students. The researcher also analyzed these strategies to find out whether they were effective when applied in mainstream classroom settings. This research study was carried out in three elementary school classrooms where teachers taught VI students in the same classroom as sighted students. Teachers had made the necessary adjustments to set accurate inclusive learning environments in their classrooms, along with the use of varied DI strategies and technology that responded to the needs and requirements for these students in their 
general classrooms. The results revealed that DI and assistive technology not only encouraged but provided students with motivation, excitement, and self-confidence when learning, helping them increase their educational independence and achieve their maximum capacity. The findings from this study revealed very positive attitudes from teachers showing eagerness to plan alternatives and use well known inclusive practices that promoted inclusive education.

Koeze (2007) found that most teachers in their study were open to receiving training and to revise the strategies they used for DI. A sample 20 teachers was divided into two groups: classrooms whose teachers received differentiation training and classrooms whose teachers did not receive the training. The results showed that teachers receiving the training demonstrated more positive actions and behavior towards planning lessons that catered for all the members of the community. Clough and Lindsay (1991) also investigated the attitudes of 584 teachers towards integration and variety of strategies and support offered to disabled students. The study revealed wider positive views of teachers regarding integration. They also found that teachers had more preferences towards integration of SEN children.

Gilmore and Cuskelly (2003) also evidenced teachers' professional growth after conducting inclusive practices. Their study focused on how teachers' and students' perceptions changed during a training program on inclusive education for children with Down syndrome. 274 pre-service teachers were surveyed at the beginning and the end of the program, revealing that students had not only obtained more knowledge about inclusion and Down syndrome in general, but their perceptions and attitudes toward inclusive education of children with Down syndrome changed positively. As regards teachers, the program increased their need for growth and training.

With regard to positive attitudes and professional development, Stanovich and Jordan (2002) found that teachers who subscribed to a disease model of teaching made a lot of attempts to reduce diversity and discrimination in the classroom. Teachers involved in the study were more persistent in their efforts to employ inclusive strategies and modify their behavior and attitudes towards this new movement.

Overall, the studies reviewed in this section revealed that teachers hold positive attitudes towards inclusive education. Teachers who had greater awareness of inclusive education tend to hold more positive attitudes which are reflected on their perceptions, actions inside the classroom, and eagerness to grow professionally. Teachers' awareness of inclusive education may lead to higher possibilities of applying and getting training regarding inclusive education. In addition, the studies showed that teachers who were attached to the idea of Inclusion developed a greater sense of leadership and felt more motivated to encourage acceptance of SEN and increase their commitment and interest to apply inclusive strategies in mainstream classrooms.

c Negative attitudes: Opinions about educating children in general classrooms differ among teachers and researchers. Despite the great benefits that inclusive programs provide to disabled leaners, reservations about including them in general classrooms are still common in the educational field (Horne and Timmons 2009), some of which are discussed below.

Lack of knowledge and resources: Lack of knowledge and resources can lead teachers to show negative feelings that may affect their understanding of disabling conditions. In a study on the attitude of teachers towards the inclusion of hard-of-hearing students in Lagos State (Nigeria), Mba (1991) found that the teacher involved in the program showed hesitation to include these students in the general education classroom. Likewise, Ogbue (1995) reported an interview conducted in Lagos State on the issue of special education and inclusion. The results demonstrated that of 200 regular teachers, $60 \%$ of them rejected inclusion and another $35 \%$ wanted it, provided they received the appropriate training. Thus many of these 
negative attitudes showed adverse effects on the learning progress and inclusion of students with special needs, since teachers had to face these challenges without support and adequate training.

Similarly, Leroy and Simpson (1996) carried out a study in the State of Michigan concerning teachers' perceptions towards the teaching of children with physical disabilities and their views towards inclusive practices. They found that teachers experience with students, particularly those with especial needs intensify their negative attitudes and confidence to teach, due to lack of expertise in this field.

A study with similar results was conducted by Heflin \& Bullock, (1999) in Ghana. Although the researchers provided significant information and scaffolding for the implementation of inclusive practices, teachers did not show positive attitudes about inclusion. They found that teachers' lack of access to resources and specialist training affected their confidence when teaching as well as their attitudes regarding the implementation of appropriate inclusive education. Leyser and Tappendorf (2001), on their part, intended to analyze and describe reasons and views of teachers towards inclusive education. They found that many regular education teachers who feel unprepared and fearful to work with learners with disabilities in regular classes display frustration, anger and negative attitudes toward inclusive education because they believe it could lead to lower academic standards from students and did not allowed them to progress in the course.

In different studies, Brownell and Carrington (2005), and Sharma et al. (2006) inquired about teachers' perceptions of inclusive education for special education students, in mainstream contexts. Results reported that general education programs supported the implementation of inclusive education programs, but it was found that there was little focus on the provision of knowledge and training of teachers in the area of managing students with disabilities and special needs.

A study conducted by Mahmoud and Hassan (2011) examined the relationship between teachers' self-efficacy and teachers' attitudes toward inclusion at preschool and primary settings. Specifically, they explored whether experience had an effect on teachers' attitudes and sense of self-efficacy. They administered a Teacher Self-Efficacy Scale to 95 primary school teachers and 71 preschool teachers. Results showed that scores on the Opinions Relevant to Integration of students with special needs (ORI) could predict scores on the test for both preschool and primary school teachers. More experienced teachers had more positive attitudes than less experienced ones. Differences were not found between preschool and primary school teachers' attitudes, but primary school teachers showed a higher sense of self-efficacy than preschool teachers regarding managing and teaching disabled pupils.

Similarly, Carroll (2003) studied the attitudes of pre-service mainstream teachers towards disabled students. The study suggested that the teachers' training program was inappropriate to prepare teachers to face these the challenge of inclusive educaiton. Thus, when teachers were given the opportunity to teach a disabled child, they felt discomfort, fear, uncertainty, vulnerability, and an inability to cope with the situation. At the end of the study teachers received training about inclusive practices and strategies, which helped them grow professionally and change their views towards disabled children.

Support and time: The following studies revealed teachers' discontent, indifference and demotivation to design inclusive contexts due lack of support and time. Mapsea, (2006) selected six primary schools in Enga Province (New Guinea) to identify and describe teachers' feelings when dealing with inclusive practices in their contexts. The study showed lack of government funding, distance from home to school, and strict cultural belief systems about disabilities influenced teachers negatively towards inclusive education.

Similarly, Wischnowski, Salmon, and Eaton (2004) examined attitudes of teachers teaching disabled children at Geneseo Central School District in New York. They found teachers believed they 
were not prepared to deal with disabled students at the same time as non-disabled ones. In addition, they pointed out that time is a good indicator of success in implementation of inclusive practices. However, they mentioned they have a lot of duties that would not allow them to handle good practices. Besides, teachers considered that the presence of disabled children could hinder the development, progress, and dynamics of the classroom since disabled children would be exposed to inappropriate social behaviors from their partners.

De Boer, Pijl, and Minnaert (2011) examined teachers' attitudes towards inclusive education, which variables are related to their attitudes, and if these affected the social participation of pupils with special needs. The study showed that most teachers held neutral and negative attitudes towards inclusion of pupils with special needs, showing indifference and de-motivation to adopt inclusive practices as a result of little training opportunities and support from the government.

Campos (2015) used a semi-structured interview in a focus group to examine physical educators' (PE) concerns about inclusion in Portugal. Findings showed that PE teachers felt cautious and neutral to the idea of inclusion. Although they pointed out that inclusion was advantageous, they raised some challenges that could be an obstacle, such as the lack of specific training and experience in inclusive $\mathrm{PE}$ and type and severity of disability. The study also revealed that the need for specific training was a key factor in the preparation of Portuguese PE teachers in inclusive education.

\section{Conclusions and directions for future research}

It is clear from the preceding review that most teachers appeared to be positive toward the overall concept of inclusion. However, there is a lot of criticism about its implementation, causing feeling of de-motivation, discontent, anxiety, and doubtfulness. Even though this article reported positive and negative views about inclusive education, the analysis indicated that a lot of work should be carried out to identify national and international inclusion needs so that teachers can be trained and schools can be equipped in order to enact appropriate inclusive practices.

By developing positive attitudes, educators can increase their enthusiasm to look for facilities and pedagogical alternatives to meet their learners' needs. However, a lot of responsibility is also attributed to educational authorities to smooth the way for inclusion. For instance, more training programs are needed to shape perceptions and attitudes towards inclusion of all members of educational communities, both in Colombia and elsewhere, in order to ensure non-discrimination and promote acceptance of disabled learners and inclusive practices in our society.

We suggest that there is a need for adopting variety of teaching tools that can help endorse teachers' general ideas to support the learning process of disabled children in mainstream classrooms. For instance, emphasis upon mix-ability teaching and DI may facilitate an inclusive curriculum and program across all discipline areas (Jelas, 2010). This way, teachers would improve their negative attitudes and concerns that prevent them from adopting inclusive practices. It is worth noting that schools and teachers need to and can effectively communicate diversity if they are aware of their teaching process and themselves.

Although research concerning teachers' attitudes towards inclusive education has increased in the last decade, research about factors and formation of positive teachers' thoughts and views towards social inclusion is needed. For instance, there should be more research about pedagogical practices and quality of training opportunities for teachers of students with especial needs. In addition, there should be a deep analysis regarding resources and accommodations for teachers to implement inclusion regarding DI, lesson planning, and material design. Studies like these will motivate teachers to continue their professional development and enrich their understanding of inclusive education. 


\section{References}

Agbenyega, J. (2007). Examining teachers'concerns and attitudes to inclusive education in Chan. International journal of Wholeschooling. 3 (1), 1-24.

Al Zyoudi, M. (2006). Teachers' Attitudes towards inclusive education in Jordanian schools. International Journal of Special Education, 21 (2), 55-63.

Australia Ministry of Education and Training. (2005). Disability Standards for Education. Canberra, Australia: Ministry of Education and Training.

Avramidis, E., Bayliss, P., \& Burden, R. (2000). A survey into mainstream teachers' attitudes towards the inclusion of children with special education needs in the ordinary school in one local education authority. Educational Psychology, 20(2), 191-225.

Beh-pajooh, A. (1992). The effect of social contact on college teachers' attitudes towards students with severe mental handicaps and their educational integration. European Journal of Special Needs Education, 7,(2) 231-236.

Bender, W. N., Vail, C. O., \& Scott, K. (1995). Teachers Attitudes toward Increased Mainstreaming Implementing Effective Instruction for Students with Learning Disabilities. Journal of Learning Disabilities, 28,(2), 87-94.

Blaz, D. (2013). Differentiated instruction: A guide for foreign language teachers. Larchmont, NY: Eye on Education.

Bowman, I. (1986). Teacher-training and the integration of handicapped pupils: some findings from a fourteen nation Unesco study. European Journal of Special Needs Education, 1, (1), 29-38.

Brownell, J., \& Carrington, S. (2005). Opportunities for authentic experienced and reflection: Ateaching program designed to change attitudes towards disability for pre-service teachers. Support for learning, 15, 99-105.

Campbell, J., Gilmore, L., \& Cuskelly, M. (2003). Changing student teachers' attitudes towards disability and inclusion. Journal of Intellectual and Developmental Disability, 28(4), 369379. http://dx.doi.org/10.1080/13668250310001616407

Campos, M., Block, M., \& Ferreira, J. (2015). Exploring teachers' voices about inclusion in physical education: a qualitative analysis with young elementary and middle school teachers. Comprehensive psychology, 4, (4) 1-9.

Carroll, A. (2003). Impact of teacher training in special education on the attitudes of Australia preservice general educators towards people with disabilities. Teacher Education Quarterly, 14, 39-60.

Clough, P., \& Lindsay, G. (1991). Integration and the Support Service: Changing roles in special education. Slough, UK: NFER.

Dev, P.C., \& Belfiore, P. (1996). Mainstreaming students with disabilities: Teacher perspectives in India: paper presented at the Annual International Convention of the Council of Exceptional Children, Orlando FL

Eagly, A. H., \& Chaiken, S. (1993). The psychology of attitudes. Fort Worth, TX: Harcourt Brace Jovanovich.

Elliot, S. (2008). The effect of teachers' attitude towards inclusion on the practice and success levels of children with and without disabilities in physical education. International Journal of Special Education, 23(3), 48-55.

Ferguson, D. L. (1995). The real challenge of inclusion: Confessions of a "rabid inclusionist". Phi Delta Kappan, 77: 281-7.

Gelzheiser, L., \& Meyers, J. (1996). Classroom teachers' views of pull-in programs. Exceptionality, $6(2), 81$. 
Gilmore, L., Campbell, J., \& Cuskelly, M.(2003).Developmental expectations, personality stereotypes, and attitudes towards inclusive education: community and teacher views of Down syndrome. International Journal of Disability, Development and Education, 50(1), 67-78.

Hall, T. (2002). Differentiated instruction. Wakefield, MA: CAST. Available: www.cast.org/ publications/ncac/ncac_diffinstruc.html

Heflin, L. J., \& Bullock, L. M. (1999). Inclusion of students with emotional/behavioural disorders: A survey of teachers in general and special education. Preventing School Failure: Alternative Education for Children and Youth, 43(3), 103-120.

Hogg, M., \& Vaughan, G. (2005). Social Psychology (4th edition). London: Prentice-Hall, pp 150.

Horne, P. E., \& Timmons, V. (2009) Making it work: Teachers' perspectives on inclusion. International Journal of Inclusive Education, 13(3), 273-286.

Inter-Agency Commission. (1990). World declaration on Education for All and framework for action to meet basic learning needs. ERIC Clearinghouse.

Jelas, Z. M. (2010). Learner Diversity and Inclusive Education: A New Paradigm for Teacher Education in Malaysia. International Conference on Learner Diversity 2010. Procedia Social and Behavioral Sciences, 7(C), 201-204. www.sciencedirect.com

Kern, E. (2006). Survey of Teacher Attitude Regarding Inclusive Education Within an Urban School District. PCOM Psychology Dissertations. Paper 70. Available:http://digitalcommons.pcom. edu/cgi/viewcontent.cgi?article $=1069 \&$ context=psychology_dissertations

Kleinert, H. L., Miracle, S., \& Sheppard-Jones, K. (2007). Including students with moderate and severe intellectual disabilities in school extracurricular and community recreation activities. Intellectual and developmental disabilities,45(1), 46-55.

Koeze, P. A. (2007). Differentiated Instruction: The Effect on Student Achievement in an Elementary School: Master's Theses and Doctoral Dissertations. Paper 31.

Leroy, B., \& Simpson, C. (1996). Improving student outcomes through inclusive education. Support for Learning, 11, (1),32-36.

Leyser, Y., Kapperman, G., \& Keller, R. (1994). Teacher attitudes towards mainstreaming: A crosscultural study in six nations. European Journal of Special Needs Education, 9, 1-15.

Leyser, Y., \& Tappendorf, K. (2001). Are attitudes regarding mainstreaming changing? A case of teachers in two rural school districts. Education, 121, 751-61

Lynn, S. G., \& Lang, P, (2005). Disability Studies in Education: Readings in Theory and Method. New York: P. Lang, C.

Mahmoud, M.., \& Hassan, M. (2011). Preschool and primary school teachers' attitudes towards inclusive education in Egypt: The role of experience and self-efficacy, Procedia - Social and Behavioral Sciences, 29, 2011, 976-985. http://dx.doi.org/10.1016/j.sbspro.2011.11.331.

Maio, G., \& Haddock, G. (2009).The psychology of attitudes and attitude change. Thousand Oaks, CA: Sage Publications

Mapsea, A. J. (2006). Teachers' views on providing for children with special needs in inclusive classrooms: a Papua New Guinea study (Thesis, Master of Special Education (MSpEd)). The University of Waikato. Retrieved from http://hdl.handle.net/10289/2391

Mastropieri, M. A., \& Scruggs, T. E. (2004). The Inclusive Classroom: Strategies for Effective Instruction (2nd ed.). Upper SadIe River, NJ: Pearson-Merrill Prentice Hall.

Mba, P. O. (1991). Elements of Special Education. Ibadan: Codat Publication Nigeria.

Mobilla, M. D. C. M. (2011). Experiencias de inclusión educactiva en Colombia: hacia el conocimiento útil. RUSC. Universities and Knowledge Society Journal,8(1), 43-65.

Ogbue, R. M. (1995). Report of the Survey of special Education Facilities in Nigeria. Lagos Federal 
Government Press.

Porter, G. L. (2008). Making Canadian schools inclusive: A call to action. Education Canada, 48(2), 62-64.

Sharma, U., Forlin, C., Loreman, T. and Earle, C. (2006). Impact of training on pre-service teachers' attitudes about inclusive education, concerns about inclusive education, and sentiments about persons with disabilities. International Journal of Special Education, 21 (2) 80-93.

Stanovich, P. J., \& Jordan, A. (2002). Preparing general educators to teach in inclusive classrooms: Some food for thought. The Teacher Educator, 37, 173-185.

Subban, P. (2005). Understanding Educator Attitudes Toward the Implementation of Inclusive Education. Disability Studies Quarterly. 25, (2), 5-26.

Thomlinson, C. A. (2000). Differentiation of Instruction in the Elementary Grades. ERIC Digest. ERIC Clearinghouse on Elementary and Early Childhood Education.

Thomson, C., D., Jones, L., Walter, J., Moore, D,W., Anderson, A. et al. (2003). Resource teacherslearning and behavior: Collaborative problem solving to support inclusion. Journal of positive behavior interventions, 5 (2), 101-111.

Unesco. (1994). The Salamanca Statement and Framework for action on special needs education: adopted by the World Conference on Special Needs Education; Access and Quality. Salamanca, Spain, 7-10 June 1994. Unesco.

Unesco. (1999) (in preparation). Inclusion in Education and National Development: Case Study on Romania.

United Nations. (2007). Convention on the Rights of Persons with Disabilities, art 24.

United Nations. General Assembly Resolution 61/295. (2007). United Nations Declaration on the Rights of Indigenous Peoples. New York, UN Headquarters.

Villa, R., Thousand, J., Meyers, H. and Nevin, A. (1996). Teacher and administrator perceptions of heterogeneous education. Exceptional Children, 63, 29-45.

Wischnowski, M. W., Salmon, S. J., \& Eaton, K. (2004). Evaluating co-teaching as a means for successful inclusion of students with disabilities in a rural district. Rural Special Education Quarterly, 23(3), 3-14.

Yara, P. O. (2009). Students attitude towards mathematics and academic achievement in some selected secondary schools in Southwestern Nigeria. European Journal of Scientific Research .36(,3), 336.

Zanna, M. P., \&Rempel, J. K. (1988). Attitudes: A new look at an old concept. In D. Bar-Tal \& W. Kruglanski (Eds.), The social psychology of knowledge (pp.315-334). Cambridge, UK: Cambridge University Press.

Zihl, J. \& Dutton, G.N. (2015). Cerebral Visual Impairment in Children: Visuo perceptive and Visuocognitive Disorders. New York: Springer. 